\title{
Providing Space for Creative Industry Sub-Sectors to Meet the Labor Market for Vocational School Graduates
}

\author{
Bayu Rahmat Setiadi \\ Department of Technology and Vocational Education \\ University of Sarjanawiyata Tamansiswa \\ Yogyakarta, Indonesia \\ bayursetiadi@gmail.com
}

\author{
Suparmin \\ Department of Technology and Vocational Education \\ University of Sarjanawiyata Tamansiswa \\ Yogyakarta, Indonesia \\ suparminust@yahoo.com
}

\begin{abstract}
Creative industry is one sector of economic booster in Indonesia that is able to increase community self-sufficiency and absorb millions of jobs. The sector is able to compete with the main sectors of foreign exchange countries such as agriculture, tourism, manufacturing, banking, and other sectors of the country's income. Since the founding of the Creative Economy Agency (Bekraf), the Indonesian government has begun to focus on preparing qualified and competitive human resources through the management of creative and dynamic creative industries. Eighteen creative industry sub-sectors such as: animation sector, architecture, design, photography, music, craft, culinary, fashion, research and development, publishing, cinema, advertising, interactive games, performing arts, visual arts, information technology, and the video becomes the belle of small and medium enterprises in DIY in competing in the national and international arena. Therefore, the fulfilment of qualified human resources in the sector in order to be dominated by vocational school graduates considering the number of unemployed graduates is quite large in Indonesia due to the amount of employment that suits their field so narrow and competitive. The distribution of vocational school graduates to the creative industries is very appropriate if based on the specialization and talents possessed by the graduates. The function of the school is to provide self-development of soft skills in accordance with the potential of students by adjusting the potential of the region that can be used as a sub-centre of creative industries in the region.
\end{abstract}

Keywords-labour market, creative industry, vocational school graduates

\section{INTRODUCTION}

Creative economic development has started since the era of the sixth president of the Republic of Indonesia and was continued by President Joko Widodo. The creative economy is able to increase the Gross Domestic Product (GDP) owned by several important sectors in Indonesia. The Ministry of Industry of the Republic of Indonesia noted that in 2012 creative economic contribution to GDP rose to Rp574 trillion or approximately $7 \%$, in addition to the creative economy sector absorb 11.8 million workers. The creative industry that developed in Indonesia was ranked 6 out of 10 compared to other industries in 2002-2008. Data generated by United
Nation in 2003 states that $50 \%$ of G7 (United States, UK, France, Canada, Italy, and France) expenditures come from creative industry products [1].

The management of the creative economy is now selforganization after removing from the Ministry of Tourism. The Creative Economy Agency (Bekraf) is the first institution established by President Joko Widodo as a non-ministerial government agency under the responsibility of the President and the government of tourism. Bekraf has the primary duty of assisting the President in formulating, defining, coordinating and synchronizing related creative economic policies to 18 long-term designed sub-sectors up to The year 2025. Eighteen subsectors including sectors (1) animation; (2) architecture; (3) design; (4) photography; (5) music; (6) crafts; (7) culinary; (8) Mode; (9) research and development; (10) publishing; (11) film; (12) advertising; (13) interactive games; (14) performing arts; (15) arts; (16) information technology; (17) television and radio; and (18) videos.

The growth of creative industry in Indonesia is in line with the growth of employment in Indonesia. Labor productivity in the creative industry sector is quite good. The report of Mari (2008) shows that the increase in labour productivity starting from 2006 can outperform agriculture, livestock, forestry, fishery, community services, trade, hotels and restaurants. This indicates that the presence of creative industries can reduce the unemployment rate in Indonesia.

Daerah Istimewa Yogyakarta is one of the provinces in Indonesia that is able to produce young entrepreneurs capable of competing in regional, national and international scale. According to Vice Chairman of KADIN for Banking and Finance, Rosan P. Roeslani, the export value of the creative industry in Jogja continues to increase, from the US \$220 million or around $\mathrm{Rp} 2.6$ trillion in 2013 to the US \$ 242 million or around Rp 2.89 trillion In 2014. In line with that, Vice Chairman of Commission B DPRD Jogja Year 2015 Rifki Listianto, explained that the platfon of funds disbursed by the government so far is big enough that amounting to $\mathrm{Rp} 10$ million for each business group. If it refers to the above explanation, then D.I. Yogyakarta is a great place to develop creative industries that are able to compete and face challenges in the ASEAN Economic Community (AEC). 
According to Section Head of Metals and Electronic Industry, Disperindagkop and UKM DIY stated that the number of creative industry business players from 2012 is 33,882, and jumped from 2013 until 2014 to 34,977 business units and 36,456 business units. The surge is only visible in certain creative industries, such as craft, fashion, and design. Other sub-sectors of creative industries that have great potential have not been fully developed by the local government. One of the main problems faced by the DIY provincial government regarding the creative economy program is the stagnant development of several local creative industries. The absence of maximum absorption of funds to local micro-creative industries provided by the provincial government of DIY. In addition, Rifki Listianto added that the creative sector of the industry most widely touched the city government is the fashion industry. Thus, efforts should be made to empower potential communities that have both individual and group creativity capable of capturing subsectors in the creative industries.

Vocational High School (SMK) which is a formal education that is able to produce graduates who are ready to work, ready to compete, and entrepreneurship. Sakernas Data (National Labor Force Survey) 2000-2010 SMK graduates who directly work in the graduation year from 43.4 percent in 2000 increased considerably to 61.3 percent in 2010 and based on SMK 2012 principal data sent via sample 1224 SMK From 10,735 vocational schools throughout Indonesia graduates are recorded to work reached 69.59 percent with details working in the industry 53.99 percent and entrepreneurs 15.6 percent; 28.3 percent went to college and 2.12 percent were unemployed. These data indicate that the existence of SMK graduates in fulfilling employment in various sectors can provide great opportunities for vocational students who have the potential to prepare themselves in the face of such a vast work challenge.

Preparing potential vocational students as subjects in creative economy development can be an alternative strategy in developing creative industry in DIY. Students of SMK in Yogyakarta who are famous for their creative potential can be empowered and optimized effectively and efficiently. The ability of individuals or groups who have the talent and creativity in completing one of the sub-sectors of the creative economy is the target aimed at the empowerment of potential vocational students. Therefore, it is necessary to construct special labour market structure to prepare SMK graduates in order to develop creative industry in DIY. With the model of the labour market, it is expected to be applied in SMK all over Indonesia in order to explore and empower the potential of students of SMK so that the creative economy in each region can grow rapidly and solve the problems of the economy independently.

\section{DISCUSSION}

The term Creative Economy was first introduced by a character named John Howkins, author of "Creative Economy, How People Make Money from Ideas". The creative economy as "the creation of value as a result of the idea" [2]. That is the economic activities that exist in the community mostly generate ideas, not just doing routine and repetitive things. For society, generating ideas is a thing to do for progress.
Kemenparekraf RI defines creative economy as the creation of value-added ideas based on creativity of human resources (creative people) and science-based, including cultural and technological heritage [3]. Therefore, the creative economy focuses on sustainable development efforts through creativity [1].

Indonesia began to introduce creative economy in the community since the sixth President of Indonesia, Susilo Bambang Yudhoyono. Since then, the contribution of the creative economy has begun to contribute to the country's foreign exchange and widespread employment. With the success of the program, the government of Joko Widodo continues the long-term design until 2025 in the development of the creative economy in Indonesia. In the national development, creative economy has a central role in realizing the five major national long-term development mission 20052025 as stipulated in Law No. 17 of 2007, namely: (1) The realization of a society of noble, moral, ethical, civilized, and civilized; (2) The realization of a competitive nation to achieve a more prosperous and prosperous society; (3) Realization of equitable development and equality; (4) The realization of a beautiful and sustainable Indonesia; And (5) The realization of Indonesia's increasing role in international relations.

The acceleration of creative economy development until the upcoming 2025 is aimed to make Creative Economy as the driving force for the Creation of a Competitive Indonesia and a Qualified Society of Life. In the book "The Creative Economy: The New Strength of Indonesia Toward 2025 [3]" mentions that the main mission described in seventeen strategic targets are:

A. To optimize the development and conservation of competitive, dynamic and sustainable local resources to achieve two objectives, namely the creation of competitive and dynamic creative people and the realization of the protection, development and utilization of natural resources and cultural resources for the creative industries on an ongoing basis. Both goals will be achieved through four strategic objectives:

a. Increasing the quantity and quality of education that supports the creation and spread of creative people equally and sustainably;

b. Increased quantity and quality of creative workforce (creative people);

c. The creation of qualified, diverse and competitive raw materials from renewable natural resources;

d. The availability of accurate and reliable cultural resource information and can be accessed easily and quickly.

B. Developing creative industries that are competitive, growing, diverse and qualified to achieve one main goal, namely the creation of creative industries that are competitive, growing, diverse and qualified through the achievement of three strategic objectives:

a. Increased local creative entrepreneurship that is competitive and dynamic; 
b. Increased local creative business that is competitive, growing, and qualified;

c. Increased diversity and quality of local creative work.

C. Developing a conducive environment that mainstreams creativity in national development by engaging all stakeholders to achieve four key objectives, namely the creation of appropriate, accessible and competitive financing, the creation of a quality and sustainable domestic and international market expansion, the availability of infrastructure and technology Appropriate, accessible, and competitive and the creation of institutional and business climate that supports the development of creative economy through the achievement of ten strategic objectives:

a. Increased availability of financing for appropriate, accessible, and competitive local creative industries;

b. Increased penetration and diversification of the creative work market at home and abroad;

c. Increased availability of adequate and competitive infrastructure;

d. Increased availability of appropriate, accessible, and competitive technologies;

e. The creation of regulations that support the creation of a climate conducive to the development of creative economy;

f. Increased active participation of stakeholders in the development of creative economy in quality and sustainable;

g. Achieving creativity as a development paradigm and in people's lives;

h. Increased position, contribution, independence and Indonesian leadership in international fora;

i. Increased appreciation for local people, works, entrepreneurs and creative businesses at home and abroad;

j. Increased public appreciation of local natural resources and culture.

The term "Creative Industries" first appeared in the 1990s and is used to describe all industries based on the creativity that intellectual property produces [4]. The creative economy is a broad spectrum of creative industries that include, an important component of economic growth, employment and international trade in today's global era [5]. The creative economy is an ecosystem that has a relationship of interdependence between creative value chain (creative value chain); Development environment (nurturance environment); Market (market) and archiving [3]. The creative economy is not only related to the creation of economic value-added, but also the creation of social, cultural and environmental value-added. Therefore, it is necessary to develop a model of economic development that can improve competitiveness, also can improve the quality of life of the Indonesian Nation, as shown below:

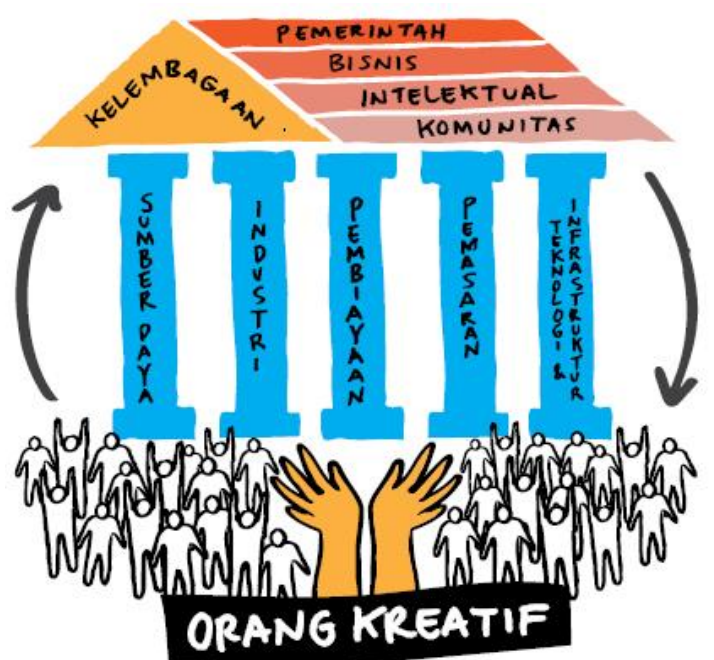

Fig. 1. Creative Economy Development Model [3]

Creative economy development model designed to meet the challenges and strategic issues that can be analogized as a building consisting of foundations, pillars and roof, which is driven by a quad-helix. The foundations of creative economic development are creative people. The pillars of creative economic development are five, namely, creative resources in the form of natural resources and cultural resources, industries consisting of core creative industry and backward and forward linkage creative industry, financing, technology and infrastructure, and marketing. This pillar will be reinforced by quad-helix through institutional norms, values, rules and legal laws governing the interaction of key actors (intellectuals, businesses, communities and governments) in the development of the creative economy. Solid foundations, strong pillars and institutional harmonies are key to the development of the creative economy.

The creative industries that developed in Indonesia experienced two revisions process. At the beginning of the year, the creative industry is divided into 15 subsectors. In the creative economy development plan 2015-2019, 15 subsectors are broken down into 18 subsectors by separating sub-sectors of film, video, photography, and animation. Eighteen creative industry sub-sectors developed in Indonesia include:

1) Animation, creative activities related to computer-based animation with manufacturing techniques that can be displayed in all types of media, namely: widescreen animation, animated TV series, animated ads, web animation, and animation games, during the manufacture, is still using a computer or a combination of Computer and manual.

2) Architecture, creative activities related to interior design, landscape architecture, civil engineering, and building service engineering. Specifically, this science can be developed on illumination techniques, acoustic techniques, façade techniques, facility specialists, and Experiential Graphic Design. 
3) Design, this creative activity is related to visual communication design, product design, and interior design. This subsector has links to other subsectors, such as publishing, advertising, animation, interactive games, architecture, film, video, photography, packaging design, crafts, and fashion. In addition, the design is also related to other economic sectors, for example, the automotive sector, transportation industry, and other industries that have output in the form of products, visuals, or processes and methods.

4) Photography, this creative activity focused on professional photography, namely journalistic photography, commercial photography, and art photography, covering the entire genre in photography, which is encouraged to enhance the added value and competitiveness of the profession of Indonesian photographers.

5) Music, creative activities are more emphasis on the development of the music industry is expected to provide economic value-added for the actors involved in it and provide quality of life for the audience. This activity is aimed at artist, songwriter, lyricist, music stylist, composer, producer, sound engineer, music director and session player.

6) Crafts, creative activities are related to art and design crafts. Art craft is limited to 2-dimensional limited edition craft and individual craft (carving, relief, carving painting), while craft design is included in mass craft, limited edition craft, and 3-dimensional individual craft (furniture, kris, jewellery, toys, fashion Custom, kitchenware, and others)

7) Culinary, this creative activity has 2 scopes, namely the field of culinary services and culinary goods. Culinary services include restaurants and catering services, while culinary items include speciality foods.

8) Mode, this creative activity is related to process type, production volume, product type, product function, and market segment. The focus of fashion development is a ready-to-wear product, both deluxe and mass production.

9) Research and development, this creative activity is emphasized in applied research and development. The availability of science can be targeted at the social, humanities, science, and technology \& engineering fields.

10)Publishing, this creative activity focuses not only on book publishing, but periodic media publishing, software, interactive games, or other publications such as music, videos, movies and animations.

11)The film, this creative activity covers the recording media and media performances used, the narration in the film, the format of the making, the genre, and the duration of the film itself.

12)Advertising, creative activities are not only limited to the marketing of products/services but also develops into social marketing, the means of building the image of a company/individual (image marketing), political campaigns and also build relationships with the community. Activities organized by the advertising industry will be wider and generate content (content), digital applications, and event procurement.

13)Interactive games, this creative activity covers an interactive game category with platforms: arcade, clientbased PCs and social and mobile media, for all genres with an emphasis on educational, advertising, serious, and casual categories.

14)Performing arts, this creative activity is related to the performing arts itself, the development or genre, group management, form-shaping, and based on the form of presentation and consumption. Performing arts are presented as art products staged to be enjoyed/consumed as art products, not as art services. Performing arts as a service can be seen in the performing arts as an event contents non-artistic culture, TV show, wedding singer, and home band. The focus of the performing arts development is dance, theatre, music, and interdisciplinary (puppets, ballets, oral literature).

15)Art, this creative activity relates to modern and contemporary art based on pure artistic values, including Traditional Fine Arts as an inspiring sector, encompassing: the entire academic sphere of applied art and pure art; And the scope of the product, whether as artwork or as a product of knowledge.

16)Information technology, creative activities are grouped by industry groups, service and product type groups and types of services and products related to the information technology industry. The focus of development includes software products and services related software.

17) Television and radio, this creative activity focuses on content development, not on broadcasting activities. The scope of television content includes four broad categories: soft news, entertainment programs, games, and music and shows, while radio content includes: news, free broadcasts, script broadcasts and music.

18) The video, this activity has a scope that can be reviewed based on the business model and its management, purpose, and genre of the video content. Video development is focused on commercial video, video and new media, and video documentation.

The potential for employment in the creative industries provides a change in the structure of the labour market in Indonesia. Many graduate schools in Indonesia are irrelevant to the field of study but work in the creative industry [6]. The main reason for these workers is because they want to develop their talents, interests, and hobbies to own businesses or work in the creative industries sub-sector. The satisfaction of the graduates working in the creative industry shows that the creative labour market potential is the perfect way to fill the job field for graduates who have not yet got a job.

Students are a society of educational environment that can be sharpened and fostered to explore deeply the potential within him. Potential student empowerment will work 
synergistically if there are several parties involved. These parties include schools, families, governments, and communities. Empowerment involving individual change and collaborative change [7]. Effective empowerment occurs when there are individual changes as well as collaborative cooperation between different partners. In addition, empowerment can be formed by a process, not instantaneously through three stages of awareness, capturing, and empowerment [8]. Awareness stage, meaning the stage of excavation of self-potential from society. Capacitative stage, meaning management of potential opportunities with the provision of training, workshops, and the like. Empowerment stage, meaning the provision of support and participation actively and sustainably according to capacity and capability.

Vocational students are students who in fact gave birth to creative, innovative, and productive generation. During schooling, they are always entrusted with an entrepreneurial spirit. The provision can be obtained by sharpening the ability of its soft skills in order to become a backup skill when they are difficult to find work. Vocational students have been first forged by practice and work so that the potential that exists within them is more subtle than high school students.

Vocational students of potential SMK can be done with the 5P approach. The 5P approach includes Possibility, Reinforcement, Protection, Support, and Maintenance [9]. The possibility is to create an atmosphere or climate that allows the student's potential to develop optimally. Strengthening is to strengthen the knowledge and ability of students in solving problems and meet their needs. Protection means protecting student's especially weak groups from being oppressed by a strong group, avoiding unbalanced competition between strong and weak and preventing the exploitation of strong and weak groups. Support is to provide guidance and support so that students are able to run the roles and duties of life. Maintenance means maintaining a conducive condition in order to avoid a balance of power distribution between different groups within the students.

\section{CONCLUSION}

Creative industry has good potential if it can be utilized in absorbing vocational school graduate and open unemployment in Indonesia especially in DIY. Special attention is required in preparing graduates who are able to be absorbed in the subsectors of the creative industries so that the students' talents, interests and soft skills can be prepared early on before competing in the creative industries labour market. The existence of eighteen sub-sectors developed in DIY is expected to provide the colour of the labour market in Indonesia and able to absorb millions of unemployed and generate thousands of creative and productive entrepreneurs.

\section{ACKNOWLEDGMENT}

This paper is dedicated to the Directorate General of Research and Development Strengthening (DRPM) of Research, Technology, and Higher Education (Ristekdikti) for his assistance in funding our research to completion.

\section{REFERENCES}

[1] M.E. Pangestu, "Pengembangan ekonomi kreatif indonesia 2025", Jakarta: Departemen Perdagangan RI, 2008.

[2] J. Howkins, "The creative economy: how people make money from ideas", London: Penguin, 2001.

[3] Kemenparekraf, "Ekonomi kreatif: kekuatan baru Indonesia menuju 2025”, Jakarta: Kementerian Pariwisata dan Ekonomi Kreatif RI, 2014.

[4] C. Henry, "Women and the creative industries: exploring the popular appeal”, Creative Industries Journal, vol.2 (2), pp.143-60, 2009.

[5] P. Higgs, and S. Cunningham, "Creative industries mapping: where have we come from and where are we going?", Creative Industries Journal, vol. 1 (1), pp. 7-30, 2008.

[6] Suparmin, P. Roniwijaya, S. Priyanto, and B.R. Setiadi, "Eksplorasi subsub sektor industri kreatif di pusat-pusat keramaian Kabupaten Kulon Progo', Procedding SENDI_U UNISBANK, pp. 712-720, 2017.

[7] P.A. Wilson, "Empowerment: community economic development from the inside out", Urban Studies, London: Carfax, vol. 33 (45), pp. 617 630, 1996.

[8] Randy R. W., and Riant N.D., Manajemen pemberdayaan: sebuah pengantar dan paduan untuk pemberdayaan masyarakat, Jakarta: PT. Elex Media Komputindo, 2007.

[9] E. Suharto, "Membangun masyarakat memberdayakan rakyat: kajian strategis pembangunan kesejahteraan sosial dan pekerjaan sosial". Bandung: Refika Aditama, 2006. 